\title{
Bowel Obstruction and Perforation as Emergency Presenting Sign of Colorectal Cancer with Peritoneal Carcinomatosis: A Case Report and Review
}

\author{
Randy Adiwinata*, Linda Rotty**, Michael Tendean ${ }^{* * *}$, Bradley Jimmy Waleleng ${ }^{* * * *}$, \\ Fandy Gosal****, Luciana Rotty****, Jeanne Winarta****, Andrew Waleleng**** \\ *Department of Internal Medicine, Faculty of Medicine, Universitas Sam Ratulangi/Prof. dr. R. D. \\ Kandou Hospital, Manado \\ ${ }^{* *}$ Division of Hematology and Medical Oncology, Department of Internal Medicine, \\ Faculty of Medicine, Universitas Sam Ratulangi/Prof. dr. R. D. Kandou Hospital, Manado \\ ${ }^{* * *}$ Division of Digestive Surgery, Department of Surgery, Faculty of Medicine, \\ Universitas Sam Ratulangi/Prof. dr. R. D. Kandou Hospital, Manado \\ ****Division of Gastroenterology-Hepatology, Department of Internal Medicine, \\ Faculty of Medicine, Universitas Sam Ratulangi/Prof. dr. R. D. Kandou Hospital, Manado
}

\section{Corresponding author:}

Randy Adiwinata. Department of Internal Medicine, Faculty of Medicine, Universitas Sam Ratulangi/Prof. dr. R. D. Kandou Hospital Manado Indonesia.Phone: +62-431-7283949. Email: randyadiwinata@yahoo.com

\begin{abstract}
Colorectal cancer patient may present with variable clinical presentation. In few cases, colorectal cancer may present as emergency such as uncontrollable gastrointestinal bleeding, large bowel obstruction and in rarer fashion is bowel perforation. Worse prognosis is linked with emergency presenting colorectal cancer. ${ }^{1}$ Peritoneal carcinomatosis may occur in 10-35\% of colorectal cancer patients and may develop bowel obstruction along with the primary colorectal cancer. ${ }^{2}$ Here, we report a-62-year-old man presented with large bowel obstruction leading to perforation without known history of colorectal cancer before. On emergency laparotomy, we found colorectal cancer and peritoneal carcinomatosis as the underlying cause. Prompt diagnosis and urgent management is warranted to improve the prognosis.
\end{abstract}

Keywords: colorectal cancer, peritoneal carcinomatosis, emergency, bowel obstruction, bowel perforation

\begin{abstract}
ABSTRAK
Pasien dengan kanker kolorektal dapat datang dengan berbagai presentasi klinis. Pada beberapa kasus, kanker kolorektal dapat datang sebagai keadaan gawat darurat seperti perdarahan saluran cerna yang tidak terkontrol, obstruksi usus besar, dan pada kasus yang lebih jarang seperti perforasi usus. Prognosis yang buruk dikaitkan dengan pasien kanker kolorektal yang datang dengan presentasi gawat darurat. Karsinomatosis peritoneal dapat muncul 10-35\% pada pasien kanker kolorektal dan dapat menjadi obstruksi usus bersama dengan kanker kolorektal primer. Pada laporan kasus ini, kami melaporkan seorang pria berusia 62 tahun dengan obstruksi usus besar yang berkembang menjadi perforasi usus, tanpa adanya riwayat kanker kolorektal sebelumnya. Pada laparotomi emergensi, kami menemukan kanker kanker dan karsinomatosis peritoneal sebagai penyebab dasar. Diagnosis dan tatalaksana yang cepat diperlukan untuk memperbaiki prognosis
\end{abstract}

Kata kunci: kanker kolorektal, karsinomatosis peritoneal, gawat darurat, obstruksi usus, perforasi usus 


\section{INTRODUCTION}

Colorectal cancer (CRC) patient may come with variable presentation mainly based on the tumor location and size. In chronic setting, CRC may come with unspecific symptoms such as changed in bowel habit e.g. alternating between constipation and diarrhea, prolonged diarrhea and constipation, bloody stool, weight loss, recurrent abdominal pain, and some with palpable abdominal mass.

However in few cases, patient with CRC may come in emergency setting such as uncontrollable gastrointestinal bleeding, large bowel obstruction and in rarer fashion is bowel perforation. Therefore, high suspicion of CRC as the underlying cause is needed to ensure prompt diagnosis and treatment; in order to improve clinical outcome. Emergency presenting colon cancer is also widely regarded as predictor of worse prognosis.

Here we report a-62-year-old man presented with large bowel obstruction leading to perforation without known history of CRC before. On emergency laparotomy, we found $\mathrm{CRC}$ and peritoneal carcinomatosis as the underlying cause.

\section{CASE ILLUSTRATION}

A-62-year-old male presented to our emergency department with recurrent diffusely periumbilical pain since one week before admissions. The pain was rated as six out of ten, according to Visual Analog Scale (VAS). He also complained abdominal distention every time he ate and having unintentional weight loss about $10 \mathrm{~kg}$ in the past two months. He denied any fever, passing bloody stool and vomiting. He denied for passing any stool since the past one week, but he still had flatus. His past medical history was unremarkable.

On physical examination, he appeared moderately ill with blood pressure of $120 / 80 \mathrm{mmHg}$, heart rate of 100 , respiratory rate of 20 , and temperature of $36.4^{\circ} \mathrm{C}$. Abdominal examination showed mild distention and tenderness on periumbilical region without muscle guarding or rigidity, diminished bowel sounds, and hypertymphanic percussion. Digital rectal examination revealed no intraluminer mass and the rectum was not collapsed. The patient first was assessed as paralytic ileus and further evaluation regarding the underlying cause was planned. The initial laboratory examination revealed anemia (hemoglobin $9.2 \mathrm{gr} / \mathrm{dL}$ ), leukocytosis $\left(23,700\right.$ cells $\left./ \mathrm{mm}^{3}\right)$, thrombocytosis $(470,000$ cells/ $\mathrm{mm}^{3}$, hyponatremia $126 \mathrm{mEq} / \mathrm{L}$, hypokalemia 3.14 $\mathrm{mEq} / \mathrm{L}$, hypoalbuminemia (2.72), normal liver and kidney function. Plain abdominal radiograph showed normal bowel gas distribution and nephrolithiasis on left kidney (Figure 1). He was treated with antibiotics and laxatives. Hyponatremia and hypokalemia was corrected. Colonoscopy for diagnostic was planned and open nasogastric tube was placed.

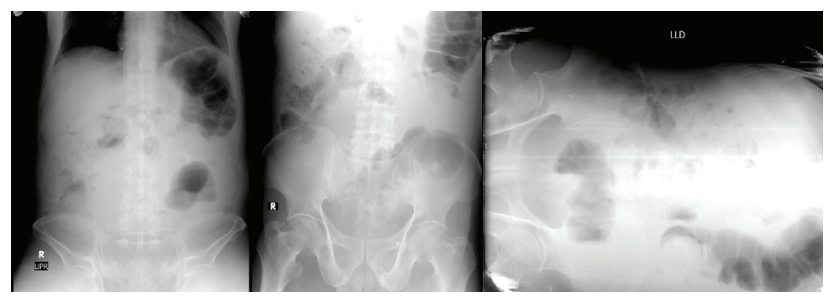

Figure 1. Plain abdominal radiograph at admission

On the third day of admission, he felt sudden severe periumbilical pain and fever. The pain was rated as eight out of ten. He also complained abdominal distension, denied vomiting, bowel movements and flatus since the severe abdominal pain occurred. Abdominal examination revealed severe distention and tenderness all over abdominal quadrant with muscle guarding and rigidity. Digital rectal examination still showed the same result as mentioned above, but diminished anal sphincter tone. Emergency plain abdominal radiograph showed sign of large bowel obstruction and perforation (Figure 2).

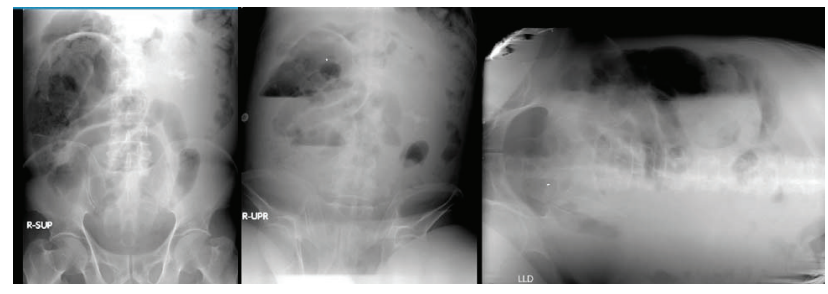

Figure 2. Plain abdominal radiograph follow up

\section{showed large bowel obstruction and perforation}

Emergency laparotomy was performed. Intraoperative findings showed large bowel perforation located approximately $40 \mathrm{~cm}$ from ileocecal valve, ascites, intraluminal colorectal mass located at the rectosigmoid junction intraluminal approximately 12$14 \mathrm{~cm}$ from anus. We also found unexpected multiple peritoneal metastasis from CRC, which suggestive of peritoneal carcinomatosis (Figure 3). We performed resection of the leakage ileum, followed with decompression of the bowel, biopsy of the tumor and peritoneal carcinomatosis (Figure 4), and the creation of loop ileostomy in the lower right quadrant of the abdomen. Due to the emergency setting and severity of this patient the definitive procedure of low anterior resection was not performed. 


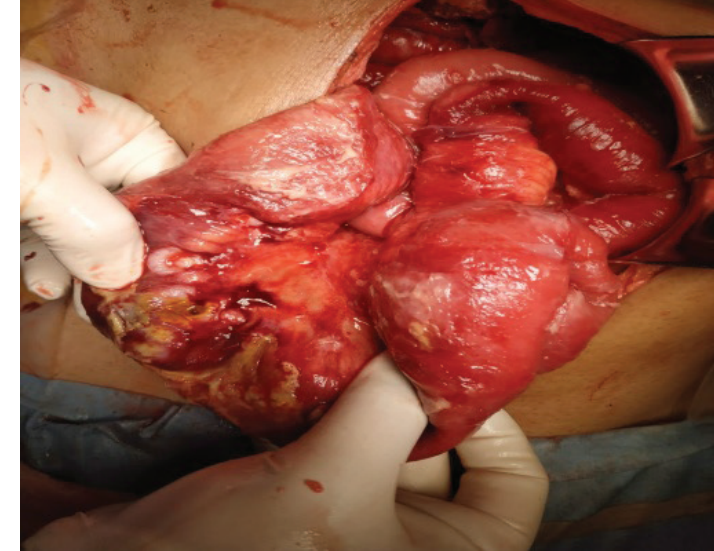

Figure 3. Intraoperative view showing perforated larger bowel, intraluminal colorectal mass, and peritoneal carcinomatosis

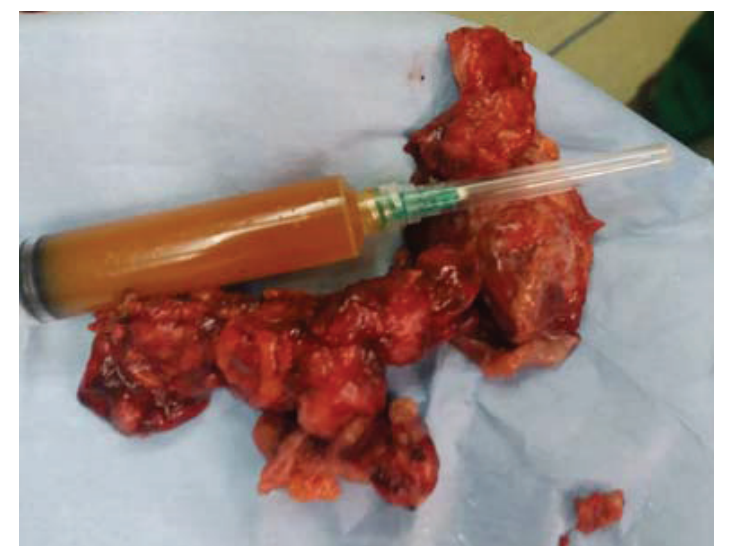

Figure 4. Resected lowel bowel and ascites sample for pathological examination

The post operative course was complicated with sepsis condition due to hospital acquired pneumonia and possibly from complicated intraabdominal infection secondary to peritonitis. He developed shortness of breath on two days post operative. Sepsis which marked with increased sequential organ failure assessment (SOFA) score to 8, which defined with low $\mathrm{PaO} 2 / \mathrm{FiO} 2$, increased bilirubin level, decreased blood pressure, impaired consciousness, and acute kidney injury. He died of sepsis 9 days after operation.

\section{DISCUSSION}

Studies showed that most CRC are diagnosed after the onset of symptoms. Clinical features of CRC are related with tumor location and size. ${ }^{3}$ Patients with right CRC usually present with subtle symptoms such as weight loss, diarrhea, and anemia, while left sided CRC patients may present with rectal bleeding and changed in bowel habit. ${ }^{4}$ However, approximately $7-40 \%$ of CRC patients may presented as emergencies which defined as having bowel obstruction perforation, or uncontrollable hemorrhage. ${ }^{1}$

\section{Epidemiology}

Studies showed that up to $30 \%$ of CRC patients are first diagnosed as emergency presentation without having prior history of CRC; as depicted in our patient that he had no prior history of CRC. Alvarez et al reported among 107 CRC patients undergoing emergency surgery, up $78 \%$ had complete bowel obstruction and $22 \%$ had perforation. ${ }^{5}$ Bass et al found that among 356 Irish patients diagnosed with CRC, up to $41 \%$ percents were found emergently and a total of $34 \%$ were having urgent colonic resection. ${ }^{6} \mathrm{~A}$ retrospective study conducted in Swedia showed rate of emergency CRC was 97/585 (17\%). ${ }^{7}$ Smothers et al found that 29 emergency surgeries were performed among 184 patient CRC patients undergoing surgery. Among those performed emergency surgeries, $72.4 \%$ were indicated for complete bowel obstruction and $20.7 \%$ for peritonitis. ${ }^{8}$ A study in Italy found that among 131 patients admitted for emergency complicated CRC, 78.3\% were admitted for bowel obstruction and $13.3 \%$ for bowel perforation. ${ }^{9}$ Review by Pisano et al concluded that large bowel obstruction as the most common emergencies related with CRC (15-30\%) and bowel perforation represented as $1-10 \%$ of CRC. ${ }^{1}$

Emergency presentation of CRC was reported more commonly found in older patients and patients with advanced stage CRC (stage III and IV cancers). ${ }^{7}$ Some reported cases showed that the median age of CRC patient with emergency presentation were approximately 65-70 years old. ${ }^{9,10}$ A larger cross sectional study in Spain which involving 950 CRC patients, found that frequency of emergency presentation was higher in women than in men with rectal cancer. ${ }^{11}$ Tebela et al reported that among 131 patients with emergency presentation of CRC, $45 \%$ of patients had left CRC, $28.3 \%$ had right CRC, and $26.7 \%$ had rectum cancer. ${ }^{9}$ Right sided, high grade, and mucinous type tumors were associated with higher risk for developing bowel obstruction. More lymph nodes involvement is associated with higher stage of CRC, and one study showed that high nodal stage defined as $\mathrm{N} 2$ was associated with $50 \%$ increased risk for developing bowel obstruction. ${ }^{10}$ World Society of Emergency Surgery (WSES) concluded that the most common location of CRC obstruction is the sigmoid colon and $75 \%$ of the tumors were located distal to splenic flexure. WSES also found that perforation is commonly found in tumor site $(70 \%)$ and the rest (30\%) was found proximal to the tumor site. ${ }^{1}$ Clearly et al conducted population based case control study 
which involving 349 CRC patients and 62 patients among them were having emergency presentations. They found that most of them $(69 \%)$ had reported symptoms of their cancer to their doctor before the emergency. Abdominal pain was strongly associated with emergency presentation of $\mathrm{CRC}$ with odds ratios of 6.0 , being followed by weight loss $(\mathrm{OR}=3.4)$ and diarrhea $(\mathrm{OR}=3.4) .{ }^{12}$

Peritoneal carcinomatosis was resulted from tumor cells in the peritoneal cavity which commonly result from the metastasis of abdominal and pelvic malignancies. Peritoneal carcinomatosis may occur in $10-35 \%$ of CRC patients. Peritoneal carcinomatosis due to CRC is commonly associated with short term recurrence, therefore limited palliative resection is mainly chosen without intention for complete reduction. Peritoneal carcinomatosis is commonly diagnosed during laparotomy or laparoscopy. Peritoneal carcinomatosis may develop bowel obstruction in some cases. Bowel obstruction due to peritoneal carcinomatosis may be mechanical or functional. ${ }^{2,13}$

\section{DIAGNOSIS}

In 2017, World Society of Emergency Surgery (WSES) issued guidelines on colon and rectal cancer emergencies, defined as obstruction and perforation. ${ }^{1}$ Diagnosis of large bowel obstruction and perforation among CRC patients may need elaborated history taking, physical examination and supported with radiological examination. Bowel obstruction may present acutely and sub acutely. Acute presentations of LBO consist of sudden colic like abdominal pain, distention, bloating, vomiting, and absence of flatus/ feces passage. While sub acute LBO presentation may consist of progressive development of symptom such as changes in bowel habit and recurrent left lower quadrant abdominal pain. Fever, rebound tenderness, muscle guarding and rigidity, absence of bowel sound may indicate peritonitis due to bowel perforation. ${ }^{1}$ As in our patient, initial complaints may not indicating bowel obstruction or perforation, however in several days he developed bowel perforation. Laboratory examination is performed to give insight of present condition of the patient and also the complication of due to bowel obstruction related dehydration, which presented as electrolyte imbalance and acute kidney injury. Leukocytosis along with neutrophilia and lactic acidosis may indicate bowel perforation or necrosis. ${ }^{1}$

WSES recommended the use of computed tomography (CT-scan) as the confirmatory diagnostic modality for detecting colon obstruction and perforation. ${ }^{1}$ CT-scan had higher specificity and sensitivity compared to abdominal ultrasound and abdominal plain X-ray. WSES recommended water soluble contrast enema as alternative for detecting site of bowel obstruction. ${ }^{1}$ However, in some Indonesian hospitals, CT-scan may not be readily available therefore abdominal plain X-ray may be utilized as screening modality for bowel obstruction and perforation. Another consideration to make before performing CT-scan in colon obstruction or perforation is the general condition and the transportability of the patient. Performing CT-scan in non-transportable and severe condition of the patient could cause mortality during the scanning process.

\section{MANAGEMENT}

The best surgical approach for patients admitted with emergency presentation for complicated CRC is still debatable. The decision in determining the best approach should be determined case by case. In some conditions, emergency resection may be performed, or in other setting damage control surgery are performed first and continued with definitive treatment in other session. ${ }^{1,9}$

Management of obstructive left colon (from distal transverse colon to the anus) consisted of several options. ${ }^{1,14}$ Resection and primary anastomosis (RPA) is the preferred option for uncomplicated malignant left sided large bowel obstruction (LBO) in absence of other risk factor. Hartmann's procedure (HP) can be considered for patients with high surgical risk better than RPA. HP should be preferred to simple colostomy, due to several reports indicated that loop colostomy is associated with longer hospital stay and the need for multiple operations. ${ }^{15-17}$ Loop colostomy should be only performed for unresectable tumors or for severely ill patients and not eligible for major surgical procedure or general anesthesia. Segmental colectomy is preferred over total colectomy in absence of caecal tears/perforation, evidence of bowel ischemia or synchronous right colonic cancers. Total colectomy is associated with higher rates of impaired bowel function. Laparoscopy usage in emergency setting currently cannot be recommended. Tube decompression can be used as option for bridge to surgery. Endoscopic stent placement using self expanded metal stent may be utilized and preferred over colostomy in palliative setting. ${ }^{1,9,14,17}$

Management of right colon obstruction also consists of several options. RPA is mainly considered as the procedure of choice. The use of SEMS as bridge 
to elective surgery is currently not recommended for obstructive right $\mathrm{CRC}$ due to the technical difficulty and further studies were needed to assess its effectiveness. However, SEMS may be utilized in palliative setting. ${ }^{1,17,18}$

The principle of cancer-related colon perforation is to control the source of sepsis and optimizing patient safety. Urgent source control and medical management should be utilized. Oncologic resection may be performed in stable cases, which consist of formal resection with or without anastomosis, with or without stoma if the perforation occurred at the tumor site. Right colectomy should be performed whenever visible. For transverse/left sided perforation at the tumor site, resection with anastomosis, with or without ileostomy should be attempted. Simultaneous tumor resection and management of proximal perforation should be performed in case of perforation proximal to tumor site..$^{1,19,20}$

In setting of unstable patients with perforation/ obstruction due to CRC, damage control surgery should be optimized and performed as soon as possible after initial resuscitation. Definitive treatment for CRC can be postponed and performed as two step surgery, as performed in this case report. In case of right sided obstruction or perforation, right colectomy with terminal ileostomy should be considered as procedure of choice. While in left sided cases, hartmann's procedure may become the procedure of choice. ${ }^{1,9,19,20}$

WSES recommended giving antibiotic prophylaxis which covering gram-negative and anerobic bacteria in case of CRC patient with bowel obstruction with no sign of systemic infection. The main consideration for this recommendation is to prevent gut microbial translocation. ${ }^{1}$ Prophylactic antibiotics should be discontinued after 24 hour or 3 doses, in order to minimize the occurrence of multidrug resistant bacteria and occurrence of opportunistic microorganisms. In case of bowel perforation, broad spectrum antibiotics should be administered timely and other supportive therapy according to sepsis guideline should be followed. ${ }^{1,21}$

Guideline regarding recommendations for bowel obstruction with peritoneal carcinomatosis was issued in France. ${ }^{13}$ Abdominal and pelvic CT-scan with contrast was recommended as initial imaging modality. Emergency surgery should be performed in case of perforation, volvulus and intestinal ischemia. Several factors should be put in consideration before surgical resection, which are cancer type, patient's age, nutritional status, performance status, radiotherapy history, and level of obstruction. Surgery may not be indicated for poor general health patient, patient with extensive carcinomatosis, multiple levels of stenosis, invasion of mesentery root, and indication for stent dilation with endoscopy. ${ }^{13}$

Alvarez et al reported mortality rate as high as 15\% among 107 patients undergoing emergency surgery for obstructing or perforating CRC. ${ }^{5}$ Bass et al found that emergency first presentation of CRC is a predictor for poorer outcome. They found lower median survival time for patients treated electively compared to emergently ( 82 months vs. 59 months) ${ }^{6}$ Gunarrsson et al showed that patients with emergency presentation of CRC had significantly lower crude 5 -year survival rate $(18 \%$ vs. $38 \%, p<0.001)$ and had doubled risk for death within five years (Hazard ratio: 2.25[95\% CI: 1.42-3.55]). ${ }^{7}$ Higher surgical morbidity were reported by Smothers et al (64 \% vs. 24\%) and higher surgical mortality was found among patients undergoing emergency surgery compared to elective surgery $(34 \%$ vs. $7 \%){ }^{8}$

CRC which presenting as emergency, such as bowel obstruction or perforation, is associated with poorer outcome and long term survival. Routine CRC screening may become key to decrease complicated $\mathrm{CRC}$ that needs emergency surgery. WSES guideline may give insight to best approach management for CRC related bowel obstruction and perforation.

\section{REFERENCES}

1. Pisano M, Zorcolo L, Merli C, Cimbanassi S, Poiasina E, Ceresoli M, et al. 2017 WSES guidelines on colon and rectal cancer emergencies: obstruction and perforation. World journal of emergency surgery: WJES 2018;13:36.

2. Coccolini F, Gheza F, Lotti M, Virzì S, Iusco D, Ghermandi $\mathrm{C}$, et al. Peritoneal carcinomatosis. World J Gastroenterol 2013;19:6979-94.

3. Hamilton W, Round A, Sharp D, Peters TJ. Clinical features of colorectal cancer before diagnosis: a population-based case-control study. Br J Cancer 2005;93:399-405.

4. Ulanja MB, Rishi M, Beutler BD, Sharma M, Patterson DR, Gullapalli N, et al. Colon Cancer Sidedness, Presentation, and Survival at Different Stages. J Oncol 2019;2019:4315032.

5. Alvarez JA, Baldonedo RF, Bear IG, Truán N, Pire G, Alvarez P. Presentation, treatment, and multivariate analysis of risk factors for obstructive and perforative colorectal carcinoma. American journal of surgery 2005;190:376-82.

6. Bass G, Fleming C, Conneely J, Martin Z, Mealy K. Emergency first presentation of colorectal cancer predicts significantly poorer outcomes: a review of 356 consecutive Irish patients. Diseases of the colon and rectum 2009;52:67884.

7. Gunnarsson H, Holm T, Ekholm A, Olsson LI. Emergency presentation of colon cancer is most frequent during summer. Colorectal disease : the official journal of the Association of Coloproctology of Great Britain and Ireland 2011;13:663-8. 
8. Smothers L, Hynan L, Fleming J, Turnage R, Simmang C, Anthony T. Emergency surgery for colon carcinoma. Diseases of the colon and rectum 2003;46:24-30.

9. Tebala GD, Natili A, Gallucci A, Brachini G, Khan AQ, Tebala $D$, et al. Emergency treatment of complicated colorectal cancer. Cancer Manag Res 2018;10:827-38.

10. Winner M, Mooney SJ, Hershman DL, Feingold DL, Allendorf JD, Wright JD, et al. Incidence and predictors of bowel obstruction in elderly patients with stage IV colon cancer: a population-based cohort study. JAMA surgery 2013;148:715-22.

11. Esteva M, Ruidíaz M, Sánchez MA, Pértega S, Pita-Fernández $\mathrm{S}$, Macià F, et al. Emergency presentation of colorectal patients in Spain. PloS one 2018;13:e203556-e.

12. Cleary J, Peters TJ, Sharp D, Hamilton W. Clinical features of colorectal cancer before emergency presentation: a populationbased case-control study. Family practice 2007;24:3-6.

13. Laval G, Marcelin-Benazech B, Guirimand F, Chauvenet L, Copel L, Durand A, et al. Recommendations for bowel obstruction with peritoneal carcinomatosis. Journal of pain and symptom management 2014;48:75-91.

14. Webster PJ, Aldoori J, Burke DA. Optimal management of malignant left-sided large bowel obstruction: do international guidelines agree? World Journal of Emergency Surgery 2019;14:23.

15. Grundmann RT. Primary colon resection or Hartmann's procedure in malignant left-sided large bowel obstruction? The use of stents as a bridge to surgery. World J Gastrointest Surg 2013;5:1-4.

16. Trompetas V. Emergency management of malignant acute left-sided colonic obstruction. Annals of the Royal College of Surgeons of England 2008;90:181-6.

17. Ansaloni L, Andersson RE, Bazzoli F, Catena F, Cennamo $\mathrm{V}$, Di Saverio S, et al. Guidelenines in the management of obstructing cancer of the left colon: consensus conference of the world society of emergency surgery (WSES) and peritoneum and surgery $(\mathrm{PnS})$ society. World journal of emergency surgery: WJES 2010;5:29.

18. Sawai RS. Management of colonic obstruction: a review. Clin Colon Rectal Surg 2012;25:200-3.

19. Schwenter F, Morel P, Gervaz P. Management of obstructive and perforated colorectal cancer. Expert review of anticancer therapy 2010;10:1613-9.

20. Lee-Kong S, Lisle D. Surgical Management of Complicated Colon Cancer. Clin Colon Rectal Surg 2015;28:228-33.

21. Mazuski JE, Tessier JM, May AK, Sawyer RG, Nadler EP, Rosengart MR, et al. The Surgical Infection Society Revised Guidelines on the Management of Intra-Abdominal Infection. Surg Infect (Larchmt) 2017;18:1-76. 